\title{
Teaching Grammar: Professional Needs of Saudi EFL Instructors
}

\author{
Anas Almuhammadi ${ }^{1}$ \\ ${ }^{1}$ English Language Institute, King Abdul Aziz University, Jeddah, KSA \\ Correspondence: Anas Almuhammadi, English Language Institute, King Abdul Aziz University, Jeddah, KSA. \\ E-mail: anashamd55@gmail.com
}

Received: January 25, 2020 Accepted: March 2, 2020 Online Published: March 7, 2020

doi:10.5539/ijel.v10n3p14 URL: https://doi.org/10.5539/ijel.v10n3p14

\begin{abstract}
Grammar teaching has been a long tradition in EFL instruction in various parts of the world and Saudi Arabia is no exception to this. However, various approaches to teaching grammar have emerged over a period of time. For this, professional development (PD) programs are designed to meet the EFL teachers' needs by enabling them to use a range of approaches and techniques. To do this successfully, professional needs analysis of teachers is essential. The present study investigates the beliefs of teachers regarding the use of various teaching approaches for grammar teaching and their need for professional development (PD). Questionnaire survey was conducted among 50 randomly chosen EFL teachers at a public sector university. The results showed that EFL teachers deem grammar as a foundational framework for teaching English as a foreign language. Furthermore, grammar is thought to be a major factor in developing accuracy and correct use of EFL. Moreover, the teachers have the theoretical knowledge of various grammar teaching methods using TBL, PBL and CLT. However, they need to develop practical skills for grammar instruction. Thus, the study recommends that the universities in Saudi Arabia need to arrange regular PD programs so that the EFL teachers with modern methods to teach English grammar successfully.
\end{abstract}

Keywords: grammar teaching, pedagogical beliefs, needs analysis, professional development

\section{Introduction}

There is a consensus that language teachers require continuous opportunities for professional development (Johnson \& Golomberk, 2016). To fulfill this need, there are several approaches and one of them is in-service professional development program. There are number of reasons why on-going in-service professional development (PD) is essential for teachers. Hiramatsu (2005) maintains that the pre-service training programs are not sufficient to develop required skills and techniques in ELT teachers that they need in classrooms. Secondly, ELT teachers are not updated with the current research in their field. This unawareness is caused due to their engagement in teaching for long time as noted by Yuan, Sun and Teng (2016). Besides these two reasons, the research shows that in-service professional development (PD) is capable of equipping teachers with the knowledge which guides them to shift to the role of 'agent of change' in their classrooms (Briguglio \& Watson, 2014). It is worth noting that this shift in role is pre-requisite at the university since several departments at Jeddah University have introduced English as a medium of instruction (EMI). More importantly, the ELT teachers will have an opportunity to learn from their experiences as well as the experiences of their colleagues for their professional development (Guefrachi \& Troudi, 2000). They (ibid) further argue that EFL teachers' professional development (PD) is not systematically managed; however, if the institutions ensure teachers' attendance in such programs, this is likely to yield benefits not only for EFL teachers but also for the institutions. For instance, EFL teachers will remain updated with current developments in ELT field besides having exposure to several techniques in teaching (Shawer, 2010).

\subsection{Aims and Objectives}

The present study is an attempt to fill this gap to investigate the teachers' perceptions about the role of grammar teaching and the effectiveness of various methods in grammar teaching. The study investigates the link between teachers' perceptions about using different methods and their professional needs so that effective teaching of grammar could be possible. EFL teachers as evidenced in the research of applied linguistics hold particular set of teaching assumptions and beliefs about teaching English as a foreign language. In Saudi Arabia, the EFL teachers' beliefs are a significant matter of inquiry as the EFL learners have low proficiency in English language 
and they face grammatical difficulties. It is due to the fact that teachers' pedagogical beliefs affect their classroom practices which lead to either better outcome or low proficiency in EFL learners. This study addresses the role of various teaching methods to teach grammar in English language classrooms and assess the professional needs of instructors to teach grammar effectively. The following objectives are set:

- To investigate the EFL instructors' perceptions about the role of grammar in teaching English.

- To evaluate the effectiveness of various teaching methods to teach English grammar in English language classrooms.

- To assess the needs of teachers for their professional development to teach grammar effectively

\subsection{Research Questions}

- What are the EFL instructors' perceptions about the role of grammar in teaching English?

- What are the views of EFL instructors about effective methods of teaching grammar?

- What are needs of teachers for their professional development to teach grammar effectively?

\section{Review of Literature}

\subsection{Needs Analysis}

Richards and Schmidt (2002) define needs analysis as a process of locating the required instruction according to the needs and requirements of the learners so that they could acquire a language. Moreover, the needs analysis also refers to prioritizing those needs and helps in decision making process. Davies et al. (2014) notes that while designing professional development (PD) programs, needs analysis is very important for the improvement in institutions. The research shows that needs analysis is to be done on the priority by the institutions when implementing and designing any professional development programs (Siedow, 1985). It is thought that when needs analysis is conducted properly, it helps in developing confidence in teachers. However, it has to ensure that needs of teachers are met; the poor structure of needs analysis may have negative impact on professional development of teachers. Kelly and Williamson (2002) show that PD programs having an appropriate curriculum will increase motivation and the spirit of teachers. This is the reason which accounts for proper design of needs analysis so that the beneficial and effective PD is implemented. A thorough look into literature validates the significance of needs analysis and its role in strengthening educators and practitioners to design a relevant and cost-effective PD program considering the needs of the institution (Mansory, 2019).

\subsection{Teaching Grammar in Saudi Arabia}

The current spirit in the literature of applied linguistics holds that grammar also supports the learning process of any foreign language (Nassaji \& Fotos, 2011; Ellis, 2008). Thus, instructional strategies on grammar play a vital role in language teaching. During the 1970s, Saudi Arabia, like most of the non-natives, followed traditional methods of teaching grammar in schools across the country (Sofi, 2015). Traditional method of grammar teaching is the type of approach which is used to teach English language through translation of grammar and vocabulary and it "concentrates more on memorization of translated rules and words from one language to another" as noted by Sofi (2015). Moreover, Borg (1998) maintains that the practices of teachers are also constructed by the cultural, mental and ecological factors of the institutions and classes. These factors consist of parents' behavior, the institute, society, principals' requirements, curriculum mandates, institutional policies, classes and school layout, colleagues, testing system and the resources available. Borg (ibid) maintains that these factors are more likely to hamper teachers' capability to adopt practices which represent their personal ideas and beliefs.

Borg (1999) noted that teachers have conflicting beliefs about teaching grammar. According to Borg (1999), grammar teaching involves a complex process of decision making. Borg further emphasizes that when the English instructors while working discussed their practices and strategies regarding teaching grammar, they went through a complex process of decision making considering a number of factors such as whether to adopt formal instruction, what language or communication skill be focused more, how to plan grammar lessons and general lesson planning, how to teach and analyze grammar according to the students' level, what kind of language practice activities to utilize, and finally, how to deal with linguistic and grammatical errors of learners. Kalsoom (2013) state that teachers favor teaching grammar explicitly while the study conducted by Aljohani (2012) maintained that grammar should be taught while considering the context; hence both form and functions need to be taken into consideration. Sofi (2015) found that in Saudi Arabia, L2 or English Language has been taught through "teacher centered classrooms by the Grammar-translation method" (p. 79). She recommends "a more communicative approach and dynamic student-centered instruction integrated grammatical input" in classrooms. 
Borg (1999) points out three kinds of experience were found influential: 1) Previous schooling of the teachers is one of those factors which continuously impact the decision making of teachers. For example, if a teacher who has learnt a foreign language through traditional method, there is likelihood that he would incorporate and employ the components of such method into a newly adopted approach (Communicative approach) to second language teaching. 2) Teachers' training and education is another important factor to have influence on the development of teachers' cognition. Pre-service and in-service training experiences help teachers negotiate between their current and past beliefs about teaching grammar. This process of negotiations impacts their cognition. 3) Real teaching experience in the classroom leaves a major effect on the cognition of teachers about language teaching. The beliefs of teachers and choice of the practices vary with the passage of time in the light of what teachers do on a day to day basis in the classroom. Their belief system and the practices get modified through conscious or unconscious process of reflection as a part of their classroom experiences.

EFL teachers' reliance on outdated pedagogical approaches consequently results in low proficiency of foreign language (Al-Seghayer, 2011; Grami, 2010). There is a dearth of research on exploring the role of teaching methods in teaching grammar which is necessary to be conducted in Saudi Arabia. In this connection, teachers' pedagogical beliefs are significant in academic sites. Borg (2009) argues that teachers' beliefs refer to a thorough knowledge of teachers' lives and their understanding of various approaches in classroom teaching which help them to make instructional choices. It is an established fact shown in research that teachers do not merely transfer linguistic knowledge to the learners, but also actively influence their teaching practices with beliefs they hold. Considering this fact, it is important to know and explore teachers' opinions and perceptions about their classroom practices. Asslahi (2013) argues that to understand teaching and learning process as a whole, understanding of teachers' beliefs stand as a foundation. A dilemma in such research establishes that most of the research on grammar teaching in terms of exploring teachers' beliefs has been conducted by native speakers in native context (Borg, 2009). There is a need to conduct research on the similar issue in non-native contexts. Moreover, it is noteworthy that much of the research available is related to pre-service teacher; in-service teachers' beliefs are yet to be explored besides investigating the role of different teaching methods in grammar teaching in English language classrooms (Canh, 2011)

\section{Methods}

The present study is quantitative in nature as it helps in gathering statistical data from larger samples of the population in the study (Creswell, 2013). The study was conducted at a public sector university in Saudi Arabia to investigate the link between teachers' perceptions about using different methods and their professional needs.

\subsection{Instrumentation}

The questionnaire was developed after reviewing literature relevant to the study topic. The questionnaire consisted of three main sections: 1) Role of Grammar in Foreign language teaching, 2) Evaluation of Grammar Teaching Methods, 3) Professional Development Needs. Each of these sections seeks to answer each research question.

\subsection{Sample and Data Collection Procedure}

As mentioned earlier, the study was conducted at a public sector university in Saudi Arabia. There are about more than 200 English instructors. A simple Random sampling method was adopted to recruit the participants. The online questionnaire was distributed among 65 teacher-participants and only 50 English instructors responded to participate in the study. Since the response rate is $70 \%$, the sample could be considered as a valid sample representative of the target population.

\subsection{Data Analysis}

The analysis was done via SPSS and the results and conclusion are displayed in the descriptive tables showing the mean value and standard deviation for each of the items in the questionnaire. All items except those related to demographic information in the questionnaire were measured on the five-point Likert scale, where 5 stands for strongly agree and 1 stands for strongly disagree.

\section{Results \& Discussion}

\subsection{EFL Instructors' Perceptions About the Role of Grammar}

The table below notes the highest mean 3.80 which is inclined to agreement on the Likert scale showing that most of the participants favored grammar instruction to be necessary in EFL instruction. The teachers believed that students need to develop conscious knowledge grammar since grammar helps in attaining accuracy in language. Moreover, they thought that grammar teaching acts as a foundational framework which opens up all 
other routes to learning the foreign language. However, the EFL teachers at the university responded that grammar affects the fluency of the ELF learners. They are less fluent when they rely on grammar in foreign language learning.

Table 1. Role of grammar in teaching a foreign language

\begin{tabular}{lll}
\hline & Mean & Std. Deviation \\
\hline A language is built on the foundation which is grammar. It's very difficult to learn a language without & 3.00 & 1.594 \\
learning grammar. & & 1.433 \\
The grammar teaching should be equally valued as other components of a language such as & & 1.729 \\
pronunciation, accuracy, vocabulary development etc. & 2.50 & 1.966 \\
The student can best learn English as a foreign language (EFL) through grammar-instructed classes. & 3.75 & 1.690 \\
Grammar is less significant in teaching English as a foreign language. & 3.80 & 1.562 \\
Grammar instruction is necessary since accuracy is possible only through grammar input in the class. & 2.05 \\
Grammar plays important role in developing the fluency of EFL learners. & 3.60 & 1.632 \\
To improve a language, students must have explicit knowledge of grammar instead of teaching it & & 1.762 \\
implicitly. & 2.70 & 1.70 \\
Implicit knowledge of grammar is more than enough to learn a foreign language.
\end{tabular}

The findings are in alignment with the study conducted by Kalsoom (2013) which show that teachers favor grammar teaching and consider grammar to be an essential factor in teaching English as a foreign language. Borg (2009) states that teachers' thorough knowledge of pedagogical beliefs influence the grammar teaching and they help in making instructional choices.

\subsection{Evaluation of Grammar Teaching Methods}

In response to use of different teaching methods in grammar teaching, the highest mean turn out to be 4.29 representing the use of Problem-based learning (PBL) in teaching grammar followed by 4.10 and 4.03 which shows that practice of grammatical structures should be carried out using communicative language teaching method (CLT). The teachers think that a thorough teaching of grammar may not help the learners develop linguistic proficiency; therefore, the input of grammar is to be given in alignment with the communicative needs of the learners. The use of language is deemed more important than just knowing about the language. Moreover, the EFL teachers responded that induction and deduction methods should be followed in grammar teaching following the instruction and examples in mother tongue of the EFL learners. Form-focused correction is helpful in developing proficiency of the learners. The table shows that teaching of grammar through repetition and imitation strategies is not helpful thus negating the behavioral theory of learning foreign languages.

Table 2. Evaluation of grammar teaching methods

\begin{tabular}{|c|c|c|}
\hline & Mean & Std. Deviation \\
\hline $\begin{array}{l}\text { Grammar rules should be taught directly, should be memorized when necessary, and should be } \\
\text { reinforced by reading and translation activities. }\end{array}$ & 2.00 & 1.464 \\
\hline $\begin{array}{l}\text { Teaching the rules of the language is important in grammar teaching and to be able to do a translation } \\
\text { between the mother language and the target language by using these rules. }\end{array}$ & 2.30 & 1.433 \\
\hline In grammar teaching, a newly-taught rule should be associated with previously-learned rules. & 3.50 & 1.529 \\
\hline Correction of grammatical errors helps students better perform in language. & 3.45 & 1.766 \\
\hline $\begin{array}{l}\text { Induction and deduction should be used in the teaching of grammar rules, and the rules should be } \\
\text { taught by comparison and explanation made in the mother language. }\end{array}$ & 3.90 & 1.640 \\
\hline $\begin{array}{l}\text { It is important to make use of various structures through memorization of dialogues in grammar } \\
\text { teaching since it will ensure the formation of a habit for language use and will reduce the errors. }\end{array}$ & 2.05 & 1.532 \\
\hline $\begin{array}{l}\text { It is an effective way to teach a grammatical structure through repetition exercises in the form of } \\
\text { "hear-repeat" in grammar teaching. }\end{array}$ & 1.60 & 1.502 \\
\hline Frequent practice and drills of structures can help students improve grammatical accuracy. & 2.70 & 1.672 \\
\hline $\begin{array}{l}\text { It is important to teach structure in a communicative context instead of teaching these as isolated } \\
\text { units. }\end{array}$ & 4.03 & 1.667 \\
\hline $\begin{array}{l}\text { Students must develop conscious awareness of structures and their functions to speak language } \\
\text { proficiently. }\end{array}$ & 1.30 & 1.423 \\
\hline Grammar should be taught through problem-based learning (PBL). & 4.29 & 1.235 \\
\hline $\begin{array}{l}\text { The language teacher should focus on bringing proficiency for the use of language skills instead of } \\
\text { transferring the grammar rules in the target language. }\end{array}$ & 4.10 & 1.533 \\
\hline
\end{tabular}


A natural process in which the mother language is learned should be followed in the teaching of the target language.

Instead of analyzing the grammar rules, only the development of the verbal lecturing skill and pronunciation should be emphasized.
3.10

1.218

2.10
1.355

The findings establish that grammar teaching is best done using a number of emerging methods and trends in teaching English as a foreign language especially PBL, communicative language teaching (CLT), naturalistic style of learning first language acquisition and others of a similar nature. Aljohani (2012) also showed that most of the teaching in EFL classes is done through GTM and does not facilitate learning successfully. Therefore, EFL teachers need to rely on a range of EFL approaches. Sofi (2015) found that EFL classrooms are more teacher-centered in Saudi Arabia and overlook the context where language is used. Communicative language teaching is less focused in Saudi Arabia as her study indicated.

\subsection{Professional Development Needs}

The findings show that there are not many opportunities available for professional development (PD) of the EFL teachers at Jeddah University, Saudi Arabia. And EFL teachers showed a moderate satisfaction of the existing PD programs. Some teachers even deemed it less significant and less need-based program due to their negligence in current trends. The table reveals that professional development programs need to be arranged on grammar teaching deductively and focusing on form and meaning instruction.

Table 3. Professional development needs

\begin{tabular}{|c|c|c|}
\hline & Mean & Std. Deviation \\
\hline I am satisfied with the availability of PD to fulfill instructional needs. & 3.06 & .819 \\
\hline Sufficient PD opportunities are provided. & 3.07 & .785 \\
\hline There are sufficient resources available for PD. & 2.93 & 1.287 \\
\hline PD is need based and data driven. & 2.71 & 1.174 \\
\hline PD sessions are in line with the mission of the Centre. & 4.01 & .456 \\
\hline PD sessions are differentiated and designed to meet individual teacher's needs. & 2.01 & .947 \\
\hline No sufficient PD sessions are arranged on Grammar teaching. & 4.35 & .892 \\
\hline There is a need to have a PD on Grammar teaching. & 4.28 & .451 \\
\hline PD on Teaching Grammar inductively & 2.16 & 1.301 \\
\hline PD on Teaching Grammar deductively & 4.28 & 1.451 \\
\hline PD on Teaching Grammar focusing on form & 3.86 & 1.829 \\
\hline PD on Teaching Grammar focusing on meaning & 3.07 & .995 \\
\hline PD on Teaching Grammar by combining forms and meaning based instruction & 3.93 & 1.887 \\
\hline PD on Teaching Grammar using Task Based Approach & 4.71 & .974 \\
\hline
\end{tabular}

According to Thorbury (1999), this inductive approach is also referred to as discovery learning which supports the inference of rules and does not focus on direct rules but rather learning indirectly by making inferences. The EFL teachers also favored the view that PD program does not facilitate the EFL teachers to learn new approaches such as TBL to teach grammar in EFL classrooms. Richards and Rodgers (2005) note that task-based learning is more meaning focused approach; it does not consciously involve rules learning. TBL is a new form of communicative teaching methodology in EFL setting. The PD programs fail to meet the needs of the EFL teachers in the present scenario. Wallace (2009) notes that teachers need to be trained professionally to deliver language knowledge effectively. Furthermore, EFL training should be made an important component at the universities taking EFL teachers' needs and demands into consideration. This research shows that transformation in teaching process is possible through PD programs when done effectively. This will develop a motivation in EFL teachers to rethink their pedagogical beliefs. Teacher training provides an opportunity to EFL learners to develop competence helping them to achieve professional growth (Wallace, 2010; Crutis \& Szestay, 2005). A study conducted by Grami (2010) showed that EFL teachers need more training on grammar teaching in terms of new approaches; and this can be achieved through effective professional development (PD) programs.

\section{Conclusion and Recommendations}

The present study was an attempt to conduct a needs analysis of professional development program to teach grammar in EFL classrooms. The study found that PD opportunities in Saudi universities are scarce; and those in practice do not fully meet the needs of EFL teachers. As a result, the study recommends that needs analysis should firstly be conducted at several other universities in Saudi Arabia to see the findings of the present study 
with others. The institutions should design need-based Professional development (PD) programs time to time to equip EFL teachers with modern teaching practices in grammar teaching. The teachers are less aware of many emerging trends in ELT; therefore, these timely and regular PD programs will enable the EFL teachers to know about various methods such as TBL, PBL, and communicative language teaching (CLT) and also integrating eclectic approach to teaching grammar. This would enable the EFL learners to better implement their teaching practices in EFL classes and turn out to be agents of change in EFL setting.

\section{References}

Aljohani, M. A. S. (2012). Grammar beliefs of in-service teachers. British Journal of Arts and Social Sciences, 11(1), 96-108.

Al-Seghayer, K. (2011). English teaching in Saudi Arabia: Status, issues, and challenges. Hala.

Assalahi, H. M. (2013). Why Is the Grammar-translation Method Still Alive in the Arab World? Teachers' Beliefs and Its implications for EFL Teacher Education. Theory \& Practice in Language Studies, 3(4). https://doi.org/10.4304/tpls.3.4.589-599

Bernard, R., \& Scampton, D. (2008). Teaching Grammar: a Survey of EAP Teaching in New Zealand. New Zealand Studies in Applied Linguistics, 14, 59-82.

Borg, S. (1998). Teachers' pedagogical systems and grammar teaching: A qualitative study. TESOL Quarterly, 32(1), 9-38. https://doi.org/10.2307/3587900

Borg, S. (1999). Teachers' theories in grammar teaching. ELT Journal, 53(3), 157-167. https://doi.org/10.1093/eltj/53.3.157

Borg, S. (2009). Introducing language teacher cognition. Retrieved from http://www.education/leeds/ac.uk/research/files/145.pdf

Briguglio, C., \& Watson, S. (2014). Embedding English language across the curriculum in higher education: A continuum of development support. Australian Journal of Language and Literacy, 37(1), 67.

Canh, L. V. (2011). Form-focused instruction: A case study of Vietnamese teachers' beliefs and practices Unpublished doctoral dissertation, University of Waikato, Hamilton.

Creswell, J. W. (2013). Steps in conducting a scholarly mixed methods study. OUP

Curtis, A., \& Szestay, M. (2005). The impact of teacher knowledge seminars: Unpacking reflective practice. TESL-EJ, 9(2), n2.

Davies, D., Jindal-Snape, D., Digby, R., Howe, A., Collier, C., \& Hay, P. (2014). The roles and development needs of teachers to promote creativity: A systematic review of literature. Teaching and Teacher Education, 41, 34-41. https://doi.org/10.1016/j.tate.2014.03.003

Ellis, R. (2008). Current Issues in the Teaching of Grammar: An SLA Perspective. TESOL Quarterly, 4O(1), 83-107. https://doi.org/10.2307/40264512

Grami, G. M. A. (2010). The effects of integrating peer feedback into university-level ESL writing curriculum: A comparative study in a Saudi context. Doctoral dissertation, Newcastle University.

Guefrachi, H., \& Troudi, S. (2000). Enhancing English language teaching in the United Arab Emirates. Teacher Education, 189-204.

Hiramatsu, S. (2005). Contexts and policy reform: A case study of EFL teaching in a high school in Japan. Second Language Teacher Education: International Perspectives, 113-134.

Johnson, K. E., \& Golombek, P. R. (2016). Mindful L2 teacher education: A sociocultural perspective on cultivating teachers' professional development. Routledge. https://doi.org/10.4324/9781315641447

Kalsoom, T. (2013). Teaching Grammar: Relationship between English Language Teachers' Beliefs and Practices. Doctoral dissertation, University of the Punjab, Lahore.

Kelly, P. P., \& Williamson, M. G. (2002). Decentralisation of professional development: teachers' decisions and dilemmas. Journal of in-service education, 28(3), 409-426. https://doi.org/10.1080/13674580200200224

Mansory, M. (2019). Conversing in L2 English with Saudi Arabic (L1) Children at Home. Arab World English Journal, 10(1). https://doi.org/10.24093/awej/vol10no1.1

Nassaji, H., \& Fotos, S. S. (2011). Teaching grammar in second language classrooms: Integrating form-focused instruction in communicative context. Routledge. https://doi.org/10.4324/9780203850961 
O'Brien, R. P. (2004). Assessing the characteristics of effective professional learning and training programs: perceptions of teachers, principals and training personnel within Catholic Education in Melbourne.

Richards, J. C., \& Rodgers, T. S. (2014). Approaches and methods in language teaching. Cambridge university press.

Schmidt, R. (2002). Racialization and language policy: The case of the USA. Multilingua, 21(2/3), 141-162.

Shawer, S. (2010). Classroom - level teacher professional development and satisfaction: teachers learn in the context of classroom - level curriculum development. Professional development in education, 36(4), 597-620. https://doi.org/10.1080/19415257.2010.489802

Shehadeh, A. (2005). Task-based language learning and teaching: Theories and applications. In Teachers exploring tasks in English language teaching (pp. 13-30). Palgrave Macmillan, London. https://doi.org/10.1057/9780230522961_2

Siedow, M. D. (1985). Inservice Education for Content Area Teachers. International Reading Association.

Sofi, L. (2015). Teaching English in Saudi Arabia through the Use of Multimedia. Master's thesis, The University of San Francisco. Retrieved from https://repository.usfca.edu/capstone/138/

Thornbury, S. (1999). How to teach grammar. Harlow, England: Pearson Education.

Wallace, M. R. (2009). Making sense of the links: Professional development, teacher practices, and student achievement. Teachers College Record, 111(2), 573-596.

Yuan, R., Sun, P., \& Teng, L. (2016). Understanding language teachers' motivations towards research. Tesol Quarterly, 50(1), 220-234. https://doi.org/10.1002/tesq.279

\section{Copyrights}

Copyright for this article is retained by the authors, with first publication rights granted to the journal.

This is an open-access article distributed under the terms and conditions of the Creative Commons Attribution license (http://creativecommons.org/licenses/by/4.0/). 